\title{
Pregnancy outcome after double renal transplant in a secondary level hospital
}

\author{
Tushar Utekar ${ }^{1 *}$, Sam Thomas ${ }^{2}$, Majda Almshwt $^{2}$, Birendra Rai ${ }^{3}$
}

\author{
${ }^{1}$ Department of Obstetrics and Gynecology, Rotunda Hospital, Dublin, Ireland \\ ${ }^{2}$ Department of Obstetrics and Gynecology, MRHM Mullingar, Ireland \\ ${ }^{3}$ Department of Paediatrics, University of Leicester, UK
}

Received: 20 March 2021

Accepted: 16 April 2021

\author{
*Correspondence: \\ Dr. Tushar Utekar, \\ E-mail: drtushar1312@gmail.com
}

Copyright: $\odot$ the author(s), publisher and licensee Medip Academy. This is an open-access article distributed under the terms of the Creative Commons Attribution Non-Commercial License, which permits unrestricted non-commercial use, distribution, and reproduction in any medium, provided the original work is properly cited.

\begin{abstract}
A 28-year-old recent migrant with no pre-conception care booked at 18 weeks of pregnancy with history of double renal transplant on left side wherein the kidney being placed in left iliac fossa. She was on cyclosporine, azathioprine, methylprednisolone the later was tapered in the first 2 months of pregnancy and was started on low dose aspirin, she had uneventful antenatal period until after 36 weeks when she developed mild preeclampsia and rising creatinine, which was managed by reducing immunosuppressant's dose and was restarted on prednisolone by discussion over telephone with nephrologist from neighbouring Regional Hospital. She had an elective LSCS at 38 weeks as requested and had a healthy male baby after steroid cover. Her intraoperative and postoperative period was uneventful as well.
\end{abstract}

Keywords: Double renal transplant, Tacrolimus, Azathioprine

\section{INTRODUCTION}

The rarity of renal transplant in pregnant women especially someone with two renal transplants which was managed successfully in a regional hospital without in house nephrologists is an important factor behind publication of this case report. The fact that she did not have any preconception care and booked at 18 weeks also made it a challenging endeavour for the staff, which ended by good neonatal and maternal outcome. In Ireland Between 19851998 there were 29 pregnancies in 19 women with live birth rate of $76 \% .^{1}$ Most of which would have been managed in tertiary care centre, under care of Renal physician. There is no data from Ireland about patients with two kidney transplants. In the UK there are about 30 40 pregnancies annually with renal transplant, with live birth rate of $91 \% .^{2,3}$

\section{CASE REPORT}

A 28-year-old lady came to booking clinic at 18 weeks of gestation in her second pregnancy the first being a miscarriage, she was assigned due date of $22^{\text {nd }}$ Dec 2015, she was a recent immigrant from an Eastern European country. She had a first trimester miscarriage in the past. Her last menstrual period was $15^{\text {th }}$ March 2015, no menstrual problems. No cervical smears done.

Her medical history was she suffered from bilateral renal failure when she was a teenager reasons unknown, in year 2001 she received her first renal transplant in her home country, which lasted for 8 years, subsequently she had a nephrectomy and was on haemodialysis from 2009-2012 when she received her second kidney again in her home country. The left kidney after transplant was placed in left iliac fossa. She has no other medical problems or had any other surgeries apart from transplant.

Her social history was non-smoker, no alcohol in pregnancy. Family history had not contributory to her condition.

Antenatal period was as follows: she did not attend any pre-conception clinic but saw nephrologist in her home 
country and then in Tullamore Hospital (Ireland) at the start of her pregnancy, both consultants were satisfied with her status and she was asked to continue tacrolimus 3 $\mathrm{mg}$ /day, azathioprine $50 \mathrm{mg} /$ day, pantoprazole $40 \mathrm{mg}$ /day and methylprednisolone $4 \mathrm{mg} /$ day which was tapered in the subsequently in the first trimester itself. Her creatinine was within normal limits, she was commenced on low dose aspirin from the booking visit and brought for an anomaly scan at 20 weeks which was normal. Her booking serology was normal including rubella immunity and she was found to be Rh negative. She was screened for gestational diabetes and was found to be negative; she continued her pregnancy without any problem with satisfactory renal functions and foetal growth.

In the $37^{\text {th }}$ week of pregnancy she developed mild to moderate preeclampsia which was managed by labetalol $100 \mathrm{mg}$ twice a day, during her stay in hospital her creatinine rose to 105 micro-mol/L when her management was discussed over phone with the consultant nephrologist from Tullamore Regional hospital, we were asked to check serum levels of her immunosuppressant's which led to increase in dose of tacrolimus to $4 \mathrm{mg} /$ day and restart prednisolone at $10 \mathrm{mg} /$ day, labetalol was stopped suspecting the reason behind her raising creatinine. Her foetal growth in last 4 weeks was monitored by departmental growth scans all of which showed satisfactory growth.

In view of her new onset preeclampsia discussion about delivery was done and was agreed between consultant and the patient to have a planned caesarean section and she had her baby on $9^{\text {th }}$ Dec 205 at 38 weeks and 1 day after receiving 2 doses of betamethasone, she had healthy male baby, and her intraoperative and postoperative period was uneventful.

\section{DISCUSSION}

Our case report shows that despite a having two renal transplants and having no pre-conception care this patient had good outcome in terms of allograft survival, neonatal outcome and absence of major obstetric complication, this is in contrast to data from UKOSS which suggested women with 2 or more transplants and raised diastolic blood pressure in $2^{\text {nd }}$ and $3^{\text {rd }}$ trimester had poor outcome. ${ }^{3}$ The study also stated a $91 \%$ live birth rate.

The favourable factors were normal creatinine $(<125$ micromol/L) levels before pregnancy. ${ }^{4}$ More than oneyear gap after transplant, absence of Gestational diabetes despite being on diabetogenic medications. ${ }^{3}$

The prophylactic low dose aspirin. ${ }^{5}$ Although our patient did develop preeclampsia it was easily managed without necessitating preterm delivery and the one episode of raised creatinine did not reach high levels $(>125$ micromol/L) to warrant it as a major complication. ${ }^{4}$ The factors that may affect kidney graft during pregnancy are as follows (Table 1). ${ }^{6}$

Table 1: The factors that may affect kidney graft in pregnancy.

\begin{tabular}{|l|}
\hline Haemodynamic changes \\
\hline Hypertension \\
\hline Impairment of renal functions \\
\hline Rejection \\
\hline Urinary tract infections \\
\hline
\end{tabular}

\section{CONCLUSION}

In summary in smaller centres without in house nephrologist can manage renal transplant patients if renal functions are optimized before pregnancy and patient low dose aspirin. ${ }^{5}$ This will give smaller units the evidence and boost in confidence to manage complex but optimized cases.

\section{Funding: No funding sources \\ Conflict of interest: None declared \\ Ethical approval: Not required}

\section{REFERENCES}

1. Kennedy C, Hussein W, Spencer S, Walshe J, Denton M, Conlon PJ, Magee C. Reproductive health in Irish female renal transplant recipients. Ir J Med Sci. 2012;181(1):5963.

2. Wiles KS, Tillett AL, Harding KR. Solid organ transplantation in pregnancy. The Obstetrician and Gynaecologist. 2016;18:189-97.

3. Bramham K, Nelson PC, Gao H, Pierce M, Bush N, Spark P, et al. Pregnancy in renal transplant recipients: a UK national cohort study. Clin J Am Soc Nephrol. 2013;8(2):290-8.

4. Deshpande NA, James NT, Kucirka LM, Boyarsky BJ, Garonzik-Wang JM, Montgomery RA, et al. Pregnancy outcomes in kidney transplant recipients: a systematic review and meta-analysis. Am $\mathrm{J}$ Transplant. 2011;11(11):2388-404.

5. Roberge $S$, Villa $P$, Nicolaides $K$, Giguère $Y$, Vainio $M$, Bakthi A, Ebrashy A, Bujold E. Early administration of low-dose aspirin for the prevention of preterm and term preeclampsia: a systematic review and meta-analysis. Fetal Diagn Ther. 2012;31(3):141-6.

6. European Association of Urology. EAU Guidelines on Renal Transplantation. Available at: https://uroweb.org/course/eau-guidelines-on-renaltransplantation/. Accessed on 10 March 2021.

Cite this article as: Utekar T, Thomas S, Almshwt M, Rai B. Pregnancy outcome after double renal transplant in a secondary level hospital. Int J Reprod Contracept Obstet Gynecol 2021;10:2062-3. 